\title{
Study on Employment Creation by Hotel Industries: A Case of Five Star Hotels of Kathmandu.
}

\section{- Krishna Chandra Jha ${ }^{1}$ and Nimananda Rijal-Ph.D.}

\begin{abstract}
.
Nepal Opened up to 1950external tourists since Sagarmatha scaled up in 1953 by Sir Edmond Hillary and Tensing Sherpa and 'The first hotel of Kathmandu was Hotel Snow View opened in early1950 to cater the tourists. Most of the workers were hired from India. Nepalese were not trained to take care of the job. Nepal soon became one of the destinations of the tourist and for trekking to virgin land of Nepal and scaling up snowcapped mountains. At present, There are 138 star hotels , 1151 Tourist Standard Hotel and 43999 hotel beds in Nepal and there are 23 five star hotels and 82 four star hotels in Nepal .Altogether one million people are employed in the hotel industries of Nepal, including home stay, guest house and restaurants.

The study found out that there are 16 five star hotels in Kathmandu with the occupancy capacity of 1343 rooms 54 restaurants in an average of 3.37 in a hotel. Total employment in five star hotels found 3065 among them 1966 male and 1099 female employees. Average Employee per hotel found 192 , the participation of women in the hotel industries found satisfactory in five star hotels of Kathmandu, the ration in between men to women calculated by the Excel program as =E19/F19, It gives direct ratio as 1966:1099 which converts as 1: 1.78. And the outcome interpreted as $1 \mathrm{~F}=$ $1.78 \mathrm{M}$. The employee should have refreshing training in their respective filed of work and the government and the hotels should come together to retain the employee by adding retirement benefits as well as upgrading policies in their respective field of work and beyond with the proper training.
\end{abstract}

Key Words: Hospitality, Hotels, Income and Employment

1 Ph.D. Scholar. 


\section{Introduction:}

Nepal is a landlocked country that shares its borders South, East and West with and the North with China. 'Nepal spreads over 147181 sq. $\mathrm{km}$ in area and lies between coordinates approximately $28^{\circ} \mathrm{N}$ and $84^{\circ} \mathrm{E}$. Nepal falls in the temperature zone north of Tropic of Cancer. Nepal is relatively a small country that only makes up $0.1 \%$ of the earth surface and it stretches $800 \mathrm{~km}$ from east to west while 150 to $250 \mathrm{~km}$ from north to south. (Kafle, 2020). Nepal is also known as the country of biodiversity due to its geographical layout, which consists of the Himalayan region, transHimalayan region, mid hill region and Terai or the plains region. The current population of Nepal is $\mathbf{2 9 , 8 4 4 , 5 4 9}$ as of Tuesday, November 9, 2021. (UN, 2021).

The economy of Nepal gradually shifting from Agriculture based to non-agriculture sectors, still the agriculture occupy ' 33.0 percent and none agricultures 67 percent and 2015/16Among the none agriculture sector, the share of hospitality sector stood 6.9 in 2012/13 and declined to 2.2 in 2015/16 due the earth quake strike (MoF, Economic Survey , 2015/16). By issuing tourism policy 2009, the government of Nepal has put tourism sector on top of its priority and Nepal has set vision 2020 with a target of attracting two million tourists to visit to Nepal and create 1 million people employed in the sector (MoF, Economic Survey , 2015/16). The 2020 visit announced and COVID-19 made it suffer. This could be temporary setbacks for a year or two, when the pandemic will come to normal, the tourist flow will be in Nepal.

Problem statement: By adding up small portion makes the bigger-chunk of economic sector, the employment creation in five star hotels are could be small portion but this is a major tourist attraction sector for comfortable and reliable stay in the country, what really they have contributed need to identify by the studies. Till the date this sector of study is lacking in Nepal.

Purpose of the Study: The study is to find out the contribution of five star Hotel Industries to create employment and its contribution in formal and informal economy of Nepal.

\section{Objectives.}

i. Identify the contribution of five star hotel Industries in creating jobs in Kathmandu. 
ii. Constraints challenges of employee in five star hotels experienced by the five star hotels of Kathmandu.

iii. Finding out the ways of means to mitigate the problems experienced by the five star hotels in employment of Kathmandu.

\subsection{Research Methodology.}

This is a qualitative research approach with the approach of analysis of convergent methods. Primary data collection from five star hotels of Kathmandu only on the employments prior to the COVID-19, There are 15 five star hotels in Kathmandu (Hotels.com, 2021). The study will also identify the published data and approaches by the different source particularly published by the ministry of finance of Nepal on its economic survey and ministry of Tourism culture and civil aviation of Government of Nepal as well as published literature from tourism board of Nepal, World trade organization in the context of international arena and scholarly articles published in the contribution of hospitality in economic sector of Nepal

\section{The Research Design.}
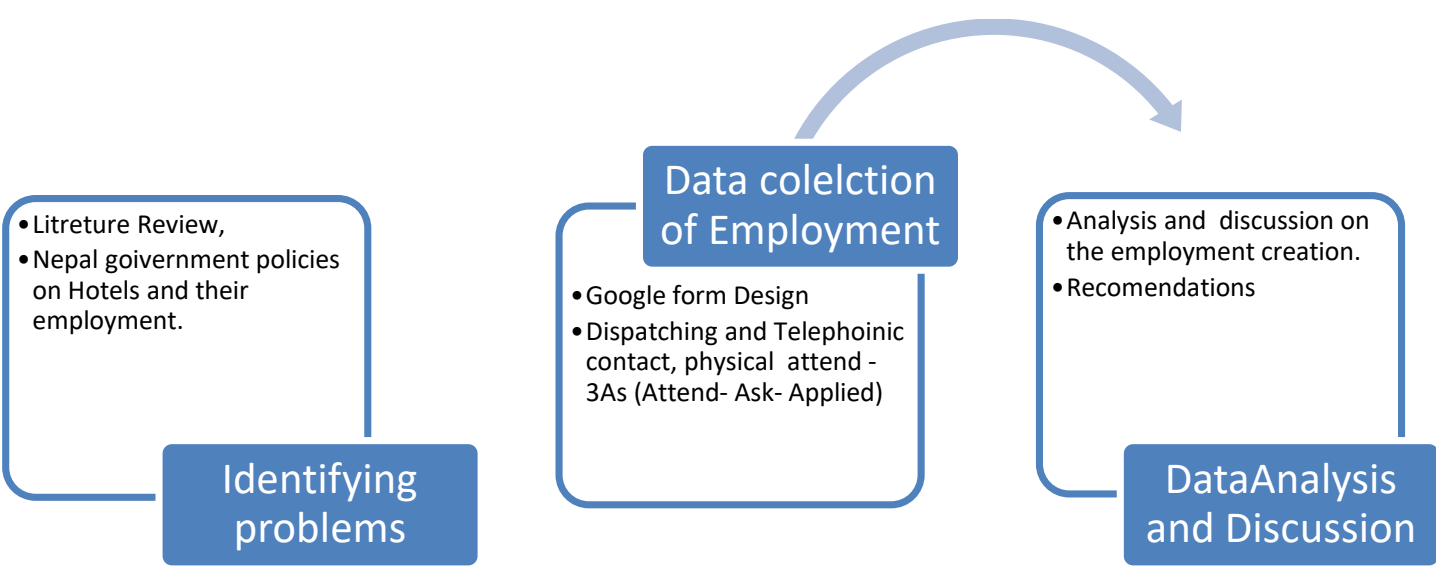


\section{Literature Review and Its' Outcome.}

\subsection{Historical back ground.}

In 1953 the first International hotel 'Royal Hotel' was established, the hotel was established by the Russian Chef 'Boris Lissanevitvc. 'In 1950, King Tribhuvan fled Nepal to find help and allies in the power struggle in Nepal. He was also in the Club 300 of Boris Lisanevich, where they met and became friends. Boris brought the king together with the right people and in 1951 the stars came together and King Tribhuvan regained power over Nepal' (Myasnikov, 2020). This time Nepalese were not involved in the hotel business, small hotels were opened in Patan but not in the form of hosting foreign dignitaries. Myasnikov further wrote on this hotel as '. He arranged the reception of Queen Elizabeth II and Prince Philip in Nepal. Hotel Royal became a place of amazing meetings - climbers, adventurers, travelers, world-scale stars, writers - the composition of guests was truly impressive. In 1960, the hotel Royal became one of the most unusual hotels in the world, and Boris himself became the second attraction of Nepal after Everest' (Myasnikov, 2020) This was an initiation of King Tribhuvan who invited Boris and provided place to open a hotel, exposed to Nepal to the outer world and he trained to Nepalese workers and Indian to maintain all the guest rooms, lobby, front yard, kitchen and other areas hygienically. People experienced the hotel can employ many people and they were also trained to keep the place neat and clean.

Hotels in Nepal: According to the data of Hotel association of Nepal ' The number of Hotels in Nepal are Star Hotels 138, Tourist standard hotels 1151 and all together No of beds 4399' (HAN, 2020). These are the only registered hotels but there are service apartments also, other hotels along the trekking routes but comfortable to live in with good facilities.

\subsection{The Government Policies in Tourism Development.}

a) To develop tourism industry and extend it, a master plan will be developed by incorporating yearly plan with periodic and action plans. b) Rural tourism will be steer head as sub tourism. Those who are not incorporating in development such as women, Madhesi, indigenous people and disadvantaged community will be incorporated in the development by establishing proper 
structure as cooperative will take place) Internal tourism will be developed as subsector of tourism. d) Tourism industry will be classified on the basis of their capacity as big, middle and small. e) The foreign investment will be allowed to invest for establishment on the basis of partnership with public and private. The model of the investment by the foreign investment with the public will be in BOOT model. f). Civil Aviation plays an important role in the development of tourism sector will be made reliable, trust worthy by the tourists. g) The role of the government will be facilitator, coordinator and motivator will be and the private sector will be encouraged to invest. $h$ ). the human resource development and management a master plan will be developed and to collect data of tourists the private sector will be involved. J). Modern communication technology will be adapted for the communication for the development of tourism industry. There are few more policies in this section' (MoCTA, $2065 \mathrm{BS}$ ).

The policy has clearly indicated three major aspects of tourism development such as i) involvement of private sector, ii). Master Plan on Human resource development and, iii) Modern communication technology adaptation. 'The World Travel \& Tourism Council (WTTC) defines direct employment contribution as employees of hotels, travel agents, airlines and passenger transport; indirect contribution includes restaurant and leisure industries supported by visitors' (Hoque, 2017)

\subsection{Employments.}

'However, as per our studies, the domestic hotel sector has been providing employment to one million workers, and 30 percent of them are female. The Hotel sector provides the highest number of employment opportunities for the female population in Nepal. Because many new hotels are coming into operation, an additional one million employment opportunities will be created in the sector in the coming five years' (Shah, 2019). The employment creation by the tourist arrivals has mixed views found in the study, one of the study estimated one tourist creates directly and indirectly nine employment (Pradhan et.al-2014) ${ }^{2}$. 'The analytical study on tourism released by the Central Bureau of Statistics recently shows that Nepal's tourism industry provides 371,140 jobs. This represents 11.5 percent of persons engaged in all industries in the country' (Prasain,

\footnotetext{
${ }^{2}$ Pradhan, H., Ghimire, G. and Subedi, S. (2014) 'Report on analysis of selected industry and service sectors in Nepal'. Submitted to Embassy of Switzerland. This was retrieved from SET publication of ODIPATHWAYS TO PROSPERITY AND INCLUSIVE JOB CREATION IN NEPAL | TOURISM SECTOR, studied by Sonia Hoque, Overseas Development Institute-2017- (s.hoque@odi.org.uk).
} 
2021). According to the Analysis made by CBS 2018, the establishment classified as Micro, which has 1-9employment, those were largest in number with 131, 526, Small 10-49 found 3128, $\begin{array}{lllllll}\text { Medium } & 50-99,128 \text { and large } 100 \quad \&+50 \quad \text { (CBS, } 2018) .\end{array}$

\subsection{Classification of Hotels in Nepal.}

'Hotel classification is the ranking of hotels, usually by using nomenclature such as stars (or diamonds), with one star denoting basic facilities and standards of comfort and five stars denoting luxury in facilities and services. The purpose is to inform intending guests in advance on what can be expected in order to reduce the gap between expected and experienced facilities and service delivery. The terms 'grading', 'rating', 'classification' and 'star rating' are used to refer to the same concept, i.e. to rank hotels by their facilities and standards' (UNWTO, 2015) ${ }^{3}$

The hotels classified in different prospective such as Based on Location, Based on Level of services and Based on Size. To classification, 'Nepal government has made and regulatory requirements to star-1 to 5 star and 5 star deluxe hotels and published in national gazette' (HAN, 2020).

\subsection{Employment and Standard of Hotel.}

The researcher have identified four and five star hotels are believed to maintain the standard as per their Stars and maintain the long term relationship to their clients/ guest (T. Kim,W.G. Kim \& H.B. Kim, 2009) The study suggest that luxury hotel have a better strategy through service guarantees to signaling firm commitment to deliver high standard of service and to reach customer maximum satisfaction.

\section{Contribution of Travel and Tourism in Employment of Nepal.}

Thousand (000)

\begin{tabular}{|l|l|l|l|l|l|l|}
\hline & \multicolumn{5}{|l|}{ Years } \\
\hline & 2005 & 2010 & 2015 & 2016 & 2017 & 2018 \\
\hline Direct & 285.86 & 347.43 & 426.40 & 452.05 & 475.82 & 497.91 \\
\hline
\end{tabular}

${ }^{3}$ Citation: World Tourism Organization (2015), Hotel Classification Systems: Recurrence of criteria in 4 and 5 stars hotels, UNWTO, Madrid, Spain, retrieved on 13/12/2021. Monday. 


\begin{tabular}{|l|l|l|l|l|l|l|}
\hline Total & 717.44 & 761.40 & 918.54 & 968.17 & 1016.47 & 1062.2 \\
\hline
\end{tabular}

Source: The Economic Journal of Nepal, Vol.41, No. 3 \& 4, July-December 2018 (Issue No. 150) (C) Cedecon-TU (S.N.12-13),

The data indicated that the direct employment rate increased almost the double within 13 years. 'Tourism is one of the areas of comparative advantage of Nepal due to its unique nature and rich cultural heritage. With a long-term vision of developing Nepal as an attractive, scenic and safe destination on the world map by conserving and promoting Nepal's natural, cultural, biological and man-made heritage, it is aimed to attract more than 2.5 million tourists and create 898,000 jobs by 2025. The year 2020 was declared as the Nepal Tourism Year with a target of attracting 2 million tourists due to the outbreak of corona-virus the campaign has been postponed' (MoF, Tourism Sector , 2020). The vision is clearly mentioned on it by the government of Nepal to create more jobs in the hospitality industries.

\subsection{Economic Contribution.}

'Hotel and restaurant sector is highly affected due to the outbreak of COVID-19 pandemic. Tourists arrivals have been reduced by 13.8 percent during July- March of current fiscal year $2019 / 20$ compared to that of the same period of fiscal year 2018/19. The gross value added of hotel and restaurant sector was expanded by 7.3 percent in fiscal year 2018/19, estimated to decrease by 16.3 percent in the current fiscal year 2019/20. Due to the disturbances in internal and external movement caused by the outbreak of COVID-19, the value added of this sector is estimated to be negative. The contribution of hotel and restaurant sector to GDP was 1.9 percent in 2018/19 fiscal year which is estimated to remain at 1.4 percent with some reduction in the current fiscal year 2019/20' (MoF, 2020)

\section{Data Collection and Analysis.}

There are fifteen five star hotels in Kathmandu, these hotels will be randomly sampled to the percentage of 40, which is higher than the number of the sampling methods, due to Covid-19, the Google forms will be sent to the sampled hotels to fill in the required information by the email, if they do not do it, then telephonic questions will be asked to the HR department of the Hotel. All the fifteen hotels are listed and the numbers are provided to them, 1 to 15, with the use of the Excel Program RANDINBETWEEN, the sample will be selected. Sample size given 14 hotels then took 
as survey in the questionnaire included all 16 five star hotels. Those are tabulated as below with their locations.

\subsection{Five star Hotels in Kathmandu, with their room occupancies.}

There is a link between the rooms and restaurants and employments, including garden and tour operation.

Table 1: Hotel room occupancy and restaurants in the hotel.

\begin{tabular}{|c|c|c|c|c|}
\hline S.N & Name & $\begin{array}{l}\text { Location in } \\
\text { KTM }\end{array}$ & Guest rooms & Restaurants \\
\hline 1 & Hyatt Place & Sundhara & 160 & 3 \\
\hline 2 & Kathmandu Marriot & Naxal & 214 & 3 \\
\hline 3 & Hyatt Regency & Boudhha & 280 & 5 \\
\hline 4 & Radisson Hotel & Lazimpat & 260 & 4 \\
\hline 5 & Aloft Kathmandu & Thamel & 167 & 3 \\
\hline 6 & Dwarikas Hotel & Gausala & $80^{4}$ & 5 \\
\hline 7 & Yak and Yeti & Naxal & 246 & 4 \\
\hline 8 & Babar mall Villas & Babarmahal & 19 & 2 \\
\hline 9 & $\begin{array}{l}\text { Soaltee Hotel ( Crown } \\
\text { Plaza) }\end{array}$ & Tahachal & 285 & 4 \\
\hline 10 & Gokarna Forest Resort & Gokarna & 100 & 3 \\
\hline 11 & Hotel Tibet International & Bouddha & 167 & 2 \\
\hline 12 & The Everest Hotel & New Baneswore & 160 & 3 \\
\hline 13 & Aria Boutique Hotel & Chhetrapati & 20 & 2 \\
\hline 14 & Shangri-La Hotel & Lazimpat & 100 & 2 \\
\hline 15 & Hotel Annapurna & Kingsway & 148 & 5 \\
\hline \multirow[t]{2}{*}{16} & Hotel Malla & Lainchaur & 98 & 4 \\
\hline & Total & & 1343 & 54 \\
\hline
\end{tabular}

Source: https://www.hotelassociationnepal.org.np/hotels/fivestar+ Primary data.

${ }^{4}$ Ref: http://dwarikas.com/ 
All together there are 1343 rooms in five star hotels of Kathmandu and 54 restaurants in an average of 3.37 in a hotel. It indicated that there is correlation in employment creation by the hotels with the restaurants as well. These restaurants will serve each time more than 2 thousands guests every day. Day and night guest, in the day time also there will be some guest for the lunch, meeting, conference and marriage parties, office parties and other get together parties, it indicates there are many employees employed by the restaurants in the hotels. As estimation they have employed more than 600 employees in the restaurants.

\subsection{Data Analysis in Employment Creation.}

Total employment in five star hotel of Kathmandu found 3065 among them 1966 male and 1099 female employees. Average Employment per hotel found 192 people, the participation of women in the hotel industries found satisfactory in five star hotels of Kathmandu, the ration in between men to women calculated Excel program as =E19/F19, It gives direct ratio as 1966:1099 which converts as 1: 1.78. And the outcome interpreted as $1 \mathrm{~F}=1.78 \mathrm{M}$.

Retention of employees is another challenge in the hospitality sector. 'Employee turnover in the hospitality industry has always been difficult to manage. This is down to a number of factors some of which aren't the fault of business owners. There are many contributing factors towards people wanting to leave the hospitality industry' (Blythe, 2021). The mean value of the question found 3.56, it means there is a lot to improve on the side of the employees, they have to be trained to the level of professionalism, when there is no professionalism in the profession, friction and earning could not make them satisfied also, this could be the one of the reason.

\subsection{Discussion on the Outcome of the Research.}

The employment in the five star hotels found an average of 192 , which should be improved and tourist stay should be increased, the effort of quality tourism has to be added in 3065 people employed directly in five-star hotels of Kathmandu. Female are also found working in good proportion almost 1:1.78 in ratio. Likewise the mean average of quality of work performed by the employee in the evaluation of employer found 3.56. it was asked in the form of likert-scale and analyzed in the Excel program. 


\section{Recommendations.}

i. The hotels effort to increase the tourist arrival is tremendous since the HAN (Hotel Association of Nepal) has been working in promoting tourism in collaboration with NTB and the government of Nepal, it should be continue with enthusiasm.

ii. Small sector that attract tourist has to be indentify, the research should be carried out to increase the employment in star hotels/ including five star hotels.

iv. Luxury tourist need to be attracted by providing safe and luxury living and travels in the country.

v. Tourism is a mixed package of different elements, such as comfort to accommodation, security, communication, safety in transportations, easy access to be in the country, easily available of visa to enter and stay to further duration, improved health and hygiene in totality, there for there is important of partnering in between the government and the private sector.

vi. Recognition of the contribution made in economic development and employment creation by the hotels should be made, they should be tax rebate to some extent to the hotels.

vii. Encouraging hotels to make the employee satisfied and see the carrier ahead in the sector and enroll in social security fund as well.

viii. Frequently skill enhancement training should be provided by the hotels and they should be given chance to upgrade their position also in the hotel itself.

The end 


\section{Bibliography}

Blythe, T. (2021, October 1). https://www.highspeedtraining.co.uk/hub/employeeretention-in- hospitality/. Retrieved 12 16, 2021, from

https://www.highspeedtraining.co.uk/hub/employee-retention-in-hospitality/:

https://www.highspeedtraining.co.uk/hub/employee-retention-in-hospitality/

CBS. (2018). Analytical Report on Tourism. Kathmandu: National Planning Commission,

Government of Nepal.

HAN. (2020, 4 10). Hotel Association of Nepal. Retrieved 12 6, 2021, from

https://www.hotelassociationnepal.org.np/pdf/Hotel\%20Data.pdf: Major

Infrastructures added to target "Visit Nepal year 2020"

Hoque, S. (2017, Octoder). PATHWAYS TO PROSPERITY AND INCLUSIVE JOB

CREATION IN NEPAL:Background Paper: Tourism sector. ODI (SET), p. 14.

Hotels.com. (2021, 12 13). Hotels.com. Retrieved 12 13, 2021, from

https://in.hotels.com/de948882-st5/five-star-hotels-in-kathmandu-nepal/:

https://in.hotels.com/de948882-st5/five-star-hotels-in-kathmandu-nepal/

Kafle, S. (2020, March). Shepherd Holidays. Retrieved Nov 10, 2021, from

https://www.shepherdholidays.com/blog/geography-of-nepal:

https://www.shepherdholidays.com/blog/geography-of-nepal

MoCTA. (2065 BS, 1 24). Torism Policy 2065. Torism policy . Kathmandu,

Bagmati, Nepal: Government of Nepal, Ministry of Culture, tourism and Civil Aviation.

MoF. (2015/16). Economic Survey . Kathmandu: Government of Nepal, Ministry of

Finance.

MoF. (2020). Economic Survey 2019/20. Kathmandu: Ministry of Finance.

Myasnikov, L. (2020). Alpine Holidays. Retrieved 11 25, 2021, from www.

Alpineholidays.com/blog: www.alpineholidaysnepal.com/blog/royalhotels.

Prasain, S. (2021, 12 14). Tourism is Nepal's fourth largest industry by employment, analytical study shows. The Kathmandu Post , p. 3.

Shah, B. (2019, 5 11). www.Newbusiness Age.com. Retrieved 12 10, 2021, from 
https://www.newbusinessage.com/MagazineArticles/view/2513:

https://www.newbusinessage.com/MagazineArticles/view/2513

T. Kim,W.G. Kim \& H.B. Kim. (2009). The effects of perceived justice on recovery satisfaction, trust, eord of mouth, and revidit intention in upscale hotels,. Tourism Mnangement, I (30), 51-62.

UN. (2021, Nov 9). www.worldometers.info/world-population. Retrieved Nov 10, 2021, from https://www.worldometers.info/world-population/nepal-population/: https://www.worldometers.info/world-population/nepal-population/ UNWTO. (2015). Claasification of Hotels. Madried, Spain: UNWTO. 